\title{
Effect of interleukin-1 $\beta$ and tumor necrosis factor $\alpha$ gene silencing on mouse gastric cancer cell proliferation and migration
}

\author{
ZHONGWEI SUN ${ }^{1}$, YAN MENG ${ }^{2}$, GUOQIN LIU ${ }^{1}$, YONGSHENG JIANG ${ }^{1}$, QINGHUA MENG ${ }^{1}$ and SANYUAN HU ${ }^{3}$ \\ ${ }^{1}$ Gastrointestinal Surgery Department and ${ }^{2}$ Operating Department, Jinan Central Hospital Affiliated to Shandong University; \\ ${ }^{3}$ General Surgery Department, Qilu Hospital Affiliated to Shandong University, Jinan, Shandong 250012, P.R. China
}

Received December 14, 2014; Accepted January 29, 2016

DOI: $10.3892 / 01.2016 .4253$

\begin{abstract}
The aim of the present study was to investigate the effect of interleukin-1 $\beta$ (IL-1 $\beta$ ) and tumor necrosis factor $\alpha$ $(\mathrm{TNF} \alpha)$ gene co-silencing in mouse gastric cancer $(\mathrm{GC})$ cells. Respectively, three pairs of liposome-encapsulated IL-1 $\beta$ and TNF $\alpha$ small interfering RNA (siRNA) were transfected into the mouse GC cell line MFC. The most effective siRNA, as identified by reverse transcription-polymerase chain reaction, was used for co-suppression of IL-1 $\beta$ and TNF $\alpha$ genes. The activities of cell proliferation, colony formation and migration were determined by the Cell Counting Kit 8 method, colony formation assay and Transwell assay, respectively. Protein array analysis was performed to identify the differentially expressed factors. The possible signaling pathways of the various factors targeting the genes were identified by pathway enrichment analysis using KOBAS 2.0. siRNA1 and siRNAc were the most effective interference sequences for IL-1 $\beta$ and TNF $\alpha$, respectively. Following co-transfection of siRNA1 and siRNAc, the expression of IL-1 $\beta$ and TNF $\alpha$ was inhibited at the mRNA and protein levels, and the cell proliferation, colony forming and migration abilities were reduced $(\mathrm{P}<0.05)$. The expression of inflammatory factors, including chemokine ligand 5, cyclooxygenase-2, IL-6, transforming growth factor $\beta$, IL-17A, matrix metallopeptidase 9 and stromal cell-derived factor $1 \alpha$ were also inhibited $(\mathrm{P}<0.05)$. These factors are mainly involved in the rheumatoid arthritis pathway, the intestinal immune network for IgA production, the TNF signaling pathway and the inflammatory bowel disease pathway. IL-1 $\beta$ and TNF $\alpha$ gene silencing inhibits the proliferation and migration of MFC. The mechanisms may involve multiple inflammatory factors that participate in the signaling pathways of tumor tissue inflammation, the immune network and TNF.
\end{abstract}

Correspondence to: Dr Sanyuan Hu, General Surgery Department, Qilu Hospital Affiliated to Shandong University, 107 Culture Road, Jinan, Shandong 250012, P.R. China

E-mail: sanyuanhuu@163.com

Key words: gastric cancer, MFC, interleukin-1 $\beta$, tumor necrosis factor $\alpha$, gene silencing, inflammatory factor

\section{Introduction}

Gastric cancer (GC) is one of the most common malignant tumors worldwide $(1,2)$ with 22,220 new cases and 10,990 mortalities in 2014 in the United States (3). Previous studies have confirmed that Helicobacter pylori (H. pylori) infection, inflammation, immune development and genetic factors are closely associated with human GC $(4,5)$. H. pylori is responsible for inducing chronic gastric inflammation that progresses to atrophy, metaplasia, dysplasia and GC $(6,7)$. The mechanism of $H$. pylori inducing GC potentially involves chronic inflammation (8) or the action of $H$. pylori virulence factors $(4,9)$. Furthermore, genetic variation in the Fas signaling pathway is correlated with the risk of GC (10). In addition, the GC-associated mortalities are mainly caused by postoperative GC cell migration in the peritoneum (11), which may result from stress reaction, acute inflammatory reaction and inflammatory factor secretion, inducing cell adhesion and migration (12). Thus, certain inflammation-related factors may be used to predict the prognosis of GC (13), and a number of immunotherapeutic strategies have been developed for GC treatment (14).

Two significant inflammatory factors, namely interleukin-1 $\beta$ (IL-1 $\beta$ ) and tumor necrosis factor $\alpha(\mathrm{TNF} \alpha)$, may be transferred to the trauma by macrophages and neutrophils, thereby promoting fibrin crosslinking and extracellular matrix remodeling, which help wounds to heal quickly (15). IL-1 $\beta$, a pro-inflammatory cytokine, plays an essential role in the generation and amplification of the inflammatory response of $H$. pylori, which strongly inhibits gastric acid secretion, causing gastric atrophy and finally inducing GC (16). TNF $\alpha$ plays a crucial role in the inflammatory response and apoptosis of tumor cells (8). It is a potent pyrogen, causing fever by direct action or by stimulation of IL-1 secretion, and it is known to stimulate cell proliferation and induce cell differentiation (17). TNF $\alpha$ promotes inflammatory cell infiltration by upregulating the expression of cell adhesion molecules in endothelial cells (18), causing the accumulation of genotoxic inflammatory byproducts and increasing the incidence of gastric mucosal damage and mutations, thereby contributing to the development of GC (9).

Therefore, we hypothesized that suppressing the expression of TNF $\alpha$ and IL-1 $\beta$ genes could contribute to the treatment of GC. This study was designed to silence the expression of TNF $\alpha$ and IL-1 $\beta$ by co-transfecting small interfering RNA (siRNA) into the GC cell line MFC. The silencing efficiency was 
confirmed by reverse transcription-polymerase chain reaction (RT-PCR) and western blot analysis in MFC cells. The cell proliferation capacity and the migration rate were compared. In addition, to further explore the underlying mechanism, a protein array technique was used to determine the expression changes of 40 inflammatory factors, and pathway enrichment analysis was performed for the differentially expressed gene-targeting proteins.

\section{Materials and methods}

Cell culture. The mouse GC cell line MFC was purchased from the Cell Bank of the Chinese Academy of Medical Sciences, Beijing, China. MFC cells were cultured in RPMI-1640 medium with $10 \%$ fetal bovine serum (FBS) in a $37^{\circ} \mathrm{C}, 5 \%$ $\mathrm{CO}_{2}$ humidity incubator. The cells at logarithmic phase were seeded in six-well plates with $2 \times 10^{5}$ cells/well overnight.

Cell transfection. Following adherence, the cells were transfected with siRNA (Dharmacon, Lafayette, CO, USA) for targeting genes (siRNA1, siRNA2 and siRNA3 for IL- $1 \beta$ silencing; siRNAa, siRNAb and siRNAc for TNFa silencing; Table I) using Lipofectamine 2000 (Invitrogen Life Technologies, Carlsbad, CA, USA) according to the manufacturer's instructions. The cells transfected with liposome-wrapped nonspecific siRNA fragment were used as controls. The MFC cells were washed with serum-free Dulbecco's modified Eagle's medium (DMEM) twice. For transfection, $10 \mu 1$ control siRNA, IL-1 $\beta$ or TNF $\alpha$ siRNA, and siRNA duplex were incubated with $3 \mu \mathrm{l}$ Lipofectamine 2000 at a final volume of $300 \mu \mathrm{l}$ in serum-free DMEM for $20 \mathrm{~min}$. The incubation buffer was then added to each well, and $4 \mathrm{~h}$ later, the RPMI-1640 medium with $10 \%$ FBS was added to each well. Transfection efficiencies were determined by RT-PCR and western blot analysis.

$R T$-PCR and western blot analysis for detection of $I L-1 \beta$ and $T N F \alpha$ silencing efficiencies. The expression of IL- $1 \beta$ and $\mathrm{TNF} \alpha$ in transfected MFC cells at the mRNA level was evaluated by RT-PCR (LightCycler 2.0, Roche Diagnostics GmbH, Mannheim, Germany) with Glyceraldehyde 3-phosphate dehydrogenase (GAPDH; Biomed Gene Technology Co., Beijing, China) as a marker. The sequences of the primers (Table II) were designed by Primer 5 (Premier Biosoft International, Palo Alto, CA, USA) and evaluated by Oligo 6 (Molecular Biology Insights, Inc., Cascade, CO, USA). The total RNA was extracted by the TRIzol method (Invitrogen Life Technologies). The amplification conditions were as follows: initial denaturation at $95^{\circ} \mathrm{C}$ for $10 \mathrm{sec}$, then 40 cycles of denaturation $\left(95^{\circ} \mathrm{C}\right.$, $3 \mathrm{~min})$, annealing $\left(56-65^{\circ} \mathrm{C}, 5 \mathrm{sec}\right)$, and extension $\left(72^{\circ} \mathrm{C}, 10 \mathrm{sec}\right)$. The annealing temperatures for IL-1 $\beta, \mathrm{TNF} \alpha$ and GAPDH were $61^{\circ} \mathrm{C}, 62^{\circ} \mathrm{C}$ and $58^{\circ} \mathrm{C}$, respectively. Reaction products were separated by agarose gel electrophoresis and visualized by Multimager (Alpha Innotech Corporation, San Leandro, CA, USA). The amplification curves were analyzed and the expression levels were calculated using the $2^{-\Delta \Delta \mathrm{Ct}}$ method.

The expression of IL-1 $\beta$ and TNF $\alpha$ in transfected MFC cells at the protein level was assayed by western blot analysis with $\beta$-actin as a marker. Cells were lysed in RIPA buffer. The protein was isolated and quantified using the bicinchoninic acid (BCA) method. Fifty micrograms of protein equaling sample was loaded in the SDS-PAGE electrophoresis system. After the proteins were transferred to the membrane, the membrane was coated with primary IL-1 $\beta$ and TNF $\alpha$ monoclonal antibody (1:1000; Abcam, Cambridge, MA, USA) for $2 \mathrm{~h}$, and then with secondary antibody (goat-anti-rat IgG; Abcam) for $2 \mathrm{~h}$. Bands were developed by enhanced chemiluminescence (Pierce, Rockford, IL, USA). Images were visualized under a Bio-Rad imaging system (Bio-Rad, Hercules, CA, USA) and analyzed by NIH image analysis software (NIH, Bethesda, MD, USA).

Cell proliferation activity. The cell proliferation activity was measured using the CCK8 kit (Dojindo Molecular Technologies, Inc., Shanghai, China). The MFC cells were seeded in 24-well plates with $1 \times 10^{4}$ cells/well. A total of $48 \mathrm{~h}$ later, CCK8 solution was added, and the optical density (OD) values at $450 \mathrm{~nm}$ were recorded $4 \mathrm{~h}$ later. The cell proliferation activity was calculated according to the following formula:

$$
\text { Proliferation activity }(\%)=\left(\mathrm{OD}_{\text {cell }}-\mathrm{OD}_{\text {black }}\right) \times 100 \% \text {, }
$$

where $\mathrm{OD}_{\text {cell }}$ is the OD value of the well with MFC and CCK8 and $\mathrm{OD}_{\text {blank }}$ is the OD value of the well with medium and CCK8 but without MFC.

Cell colony formation assay. The cells at logarithmic phase were digested with $0.25 \%$ trypsin and diluted with DMEM containing 20\% FBS to prepare a cell suspension of $1 \times 10^{6}$ cells $/ 1$. A $3 \mathrm{ml}$ mixture of $1.2 \%$ agarose and $2 \mathrm{X}$ DMEM at a ratio of 1:1 was poured into a $6-\mathrm{cm}$ culture dish. After cooling down, $0.2 \mathrm{ml}$ cell suspension was mixed with another $3 \mathrm{ml}$ mixture of $0.7 \%$ agarose and 2X DMEM medium (1:1) and then added to the dish. After incubation for 10-14 days at $37^{\circ} \mathrm{C}$ in a $5 \% \mathrm{CO}_{2}$ humidified incubator, visible colonies were counted under an inverted microscope (Diaphot 300; Nikon Corporation, Tokyo, Japan). The colony formation rate was calculated using the following formula:

Colony formation effeciency $(\%)=\frac{\text { numbers of colonies }}{\text { numbers of seeded cells }} \times 100 \%$

Transwell cell migration experiment. Cell migration was assayed by using the Transwell method. A volume of $100 \mu \mathrm{l}$ cell suspension with $5 \times 10^{5}$ cells/ 1 was added to the upper chamber of the Transwell with serum-free DMEM. The lower chamber contained DMEM with $10 \%$ FBS. The cells were incubated at $37^{\circ} \mathrm{C}$ in a $5 \% \mathrm{CO}_{2}$ humidified incubator for $6 \mathrm{~h}$ and then washed twice with $\mathrm{Ca}$-free phosphate-buffered saline (PBS). After fixing in formaldehyde for $30 \mathrm{~min}$, the Transwell was dried at room temperature and the cells were stained with $0.1 \%$ crystal violet. The non-migrated cells were removed from the upper surface of the membrane by a cotton swab and then the Transwell was washed three times with PBS. Five fields were randomly selected under the microscope (x400 magnification) to calculate the migration rate.

Protein array technology to assess the expression of inflammatory factors. Proteins were extracted with RIPA buffer, and proteomic analysis was performed using an AAM-CUST-G1 protein chip (RayBiotech, Inc., Norcross, GA, USA). The expression of proteins was determined by the BCA method, and samples with a concentration of $500 \mu \mathrm{g} / \mathrm{ml}$ protein were 
Table I. siRNA sequences of IL- $1 \beta$ and TNF $\alpha$.

\begin{tabular}{lll}
\hline Gene name & Group & \multicolumn{1}{c}{ siRNA sequence } \\
\hline IL-1 $\beta$ & siRNA1 & Sense: 5' AGAUAGAAGUCAAGAGCAAUU 3' \\
& siRNA2 & Antisense: 3' UUUCUAUCUUCAGUUCUCGUU 5' \\
& & Sense: 5' UCAACAAGAUAGAAGUCAAUU 3' \\
& siRNA3 & Antisense: 3' UUAGUUGUUCUAUCUUCAGUU 5' \\
& & Sense: 5' GCUCCGAGAUGAACAACAAUU 3' \\
TNF $\alpha$ & siRNAa & Antisense: 3' UUCGAGGCUCUACUUGUUGUU 5' \\
& & Sense: 5' GGAACUGGCAGAAGAGGCAUU 3' \\
& siRNAb & Antisense: 3' UUCCUUGACCGUCUUCUCCGU 5' \\
& SiRNAc & Sense: 5' CCCAAAGGGAUGAGAAGUUUU 3' \\
& & Antisense: 3' UUGGGUUUCCCUACUCUUCAA 5' \\
& & Sense: 5' GCAUGGAUCUCAAAGACAAUU 3' \\
& & Antisense: 3' UUCGUACCUAGAGUUUCUGUU 5'
\end{tabular}

IL-1 $\beta$, interleukin-1 $\beta$; TNF $\alpha$, tumor necrosis factor $\alpha$.

Table II. Primer sequence of IL-1 $\beta$, TNF $\alpha$ and GAPDH for RT-PCR.

\begin{tabular}{lcl}
\hline Gene name & Genbank accession no. & \multicolumn{1}{c}{ Primer sequence 5'-3' } \\
\hline IL-1 $\beta$ & NM_008361 & F: GAAATGCCACCTTTTGACAGTG \\
& & R: TGGATGCTCTCATCAGGACAG \\
TNF $\alpha$ & NM_013693 & F: CCTGTAGCCCACGTCGTAG \\
GAPDH & NM_008085 & R: GGGAGTAGACAAGGTACAACCC \\
& & F: AATGGATTTGGACGCATTGGT \\
\hline
\end{tabular}

IL-1 $\beta$, interleukin-1 $\beta$; TNF $\alpha$, tumor necrosis factor $\alpha$; GAPDH, Glyceraldehyde 3-phosphate dehydrogenase; RT-PCR, reverse transcription-polymerase chain reaction.

Table III. List of AAM-CUST-G inflammatory factors.

\begin{tabular}{lllll}
\hline BLC & CD30 ligand & CCL5 & COX-2 & Fas ligand \\
Fractalkine & GCSF & GM-CSF & IFN- $\gamma$ & IL-1 $\alpha$ \\
IL-5 & IL-2 & IL-3 & IL-4 & IL-6 \\
TGF $\beta$ & IL-10 & IL-12 p40/p70 & IL-12 p70 & IL-13 \\
IL-17A & I-TAC & KC & Leptin & LIX \\
Lymphotactin & MCP-1 & M-CSF & MIG & MIP-1 $\alpha$ \\
MMP1 & MMP2 & MMP9 & MMP10 & SDF-1 $\alpha$ \\
TIMP-1 & TIMP-2 & TIMP-4 & TNF RI & TNF RII \\
\hline
\end{tabular}

prepared. The glass slides were spotted with antibodies of 40 inflammatory factors (shown in Table III) with two repeats for each factor. After blocking with blocking buffer, each slide was incubated with $100 \mu \mathrm{l}$ protein extracts at $4^{\circ} \mathrm{C}$ overnight. The slides were washed four times for 5 minutes each time, and incubated with biotin-conjugated antibody at room temperature for $2 \mathrm{~h}$. After washing again, the slides were incubated with fluorescent-labeled streptavidin at room temperature for $1.5 \mathrm{~h}$. The intensities of the fluorescence signals of the microarray were measured using a laser microarray scanner (Axon ${ }^{\circledR}$ Genepix Professional 4000B microarray scanner, Molecular Devices LLC, Sunnyvale, CA, USA) at $532 \mathrm{~nm}$, and quantified using GenePix 3.0 software. The positive control was used to normalize the results from each slide. 

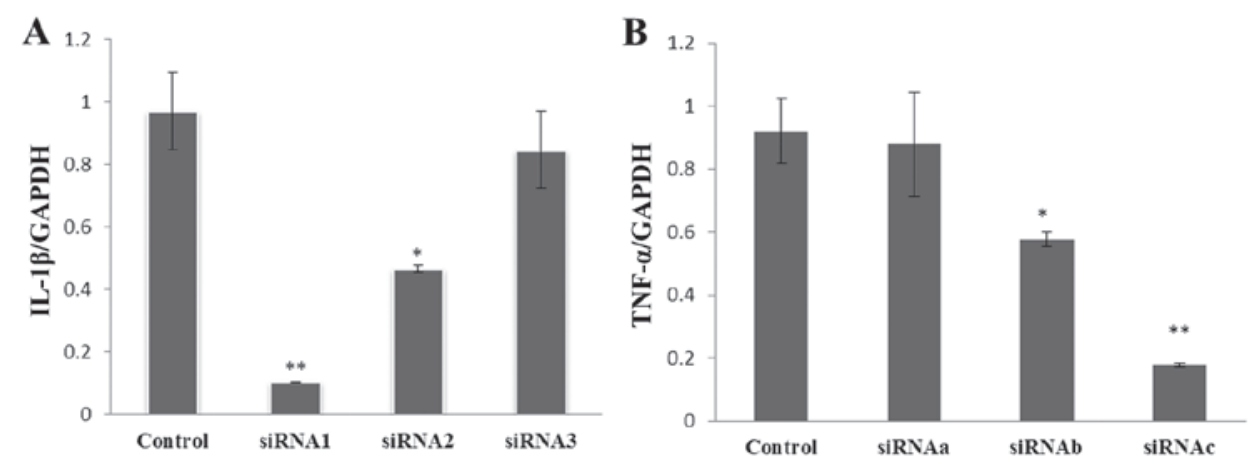

Figure 1. Silencing efficiency of (A) interleukin-1 $\beta$ (IL-1 $\beta$ ) and (B) tumor necrosis factor $\alpha$ (TNF $\alpha)$ siRNA. "P<0.05 compared with control; ${ }^{* *} \mathrm{P}<0.01$ compared with control.

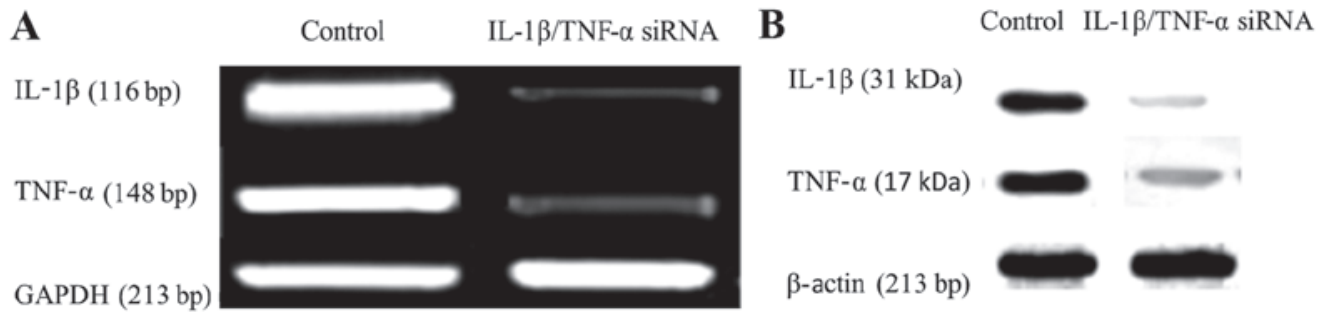

Figure 2. Expression of interleukin-1 $\beta$ (IL-1 $\beta$ ) and tumor necrosis factor $\alpha(\mathrm{TNF} \alpha)$ determined by (A) reverse transcription-polymerase chain reaction and (B) western blot analysis in the IL-1 $\beta / \mathrm{TNF} \alpha$ group and control group.
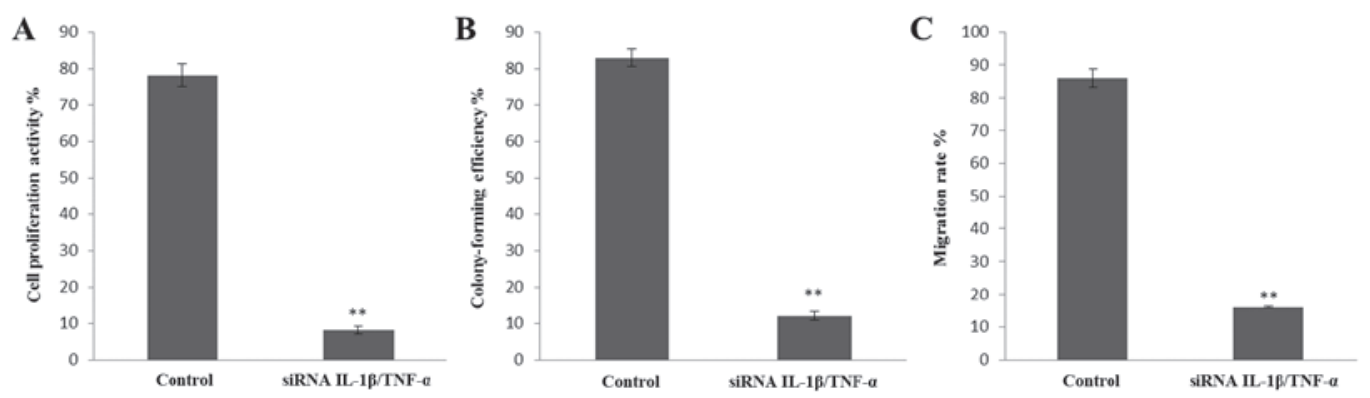

Figure 3. Effect of interleukin-1 $\beta$ (IL-1 $\beta$ )/tumor necrosis factor $\alpha(\mathrm{TNF} \alpha)$ co-silencing on (A) cell proliferation, (B) colony formation and (C) migration . ${ }^{* *} \mathrm{P}<0.01$ compared with control.

Signaling pathway analyses of differentially expressed proteins. Kyoto Encyclopedia of Genes and Genomes (KEGG) pathway enrichment analysis for the differentially expressed protein target genes was conducted using KOBAS 2.0 (http://kobas.cbi.pku.edu.cn/) (19).

Statistical analysis. Data are presented as the means \pm standard deviation (SD), and the comparisons between groups were performed by Student's t-test using SPSS 20.0 software (IBM SPSS, Armonk, NY, USA). P $<0.05$ was considered to indicate a statistically significant difference.

\section{Results}

$I L-1 \beta$ and $T N F \alpha$ silencing. Fig. $1 \mathrm{~A}$ reveals that siRNA1 and siRNA2 significantly inhibited the expression of IL-1 $\beta$ at the mRNA level (siRNA1, $\mathrm{P}<0.01$; siRNA2, $\mathrm{P}<0.05$ ), while siRNA3 had no significant effect (siRNA3, P>0.05). Similarly,
siRNAb and siRNAc, but not siRNAa, had a statistically significant $\mathrm{TNF} \alpha$ silencing effect $(\mathrm{P}<0.05$, Fig. 1B).

The most effective siRNA1 and siRNAc $(200 \mathrm{nmol} / \mathrm{l})$ were respectively used for the co-silencing of IL-1 $\beta$ and TNF $\alpha$ in MFC. Following co-transfection, the expression of IL-1 $\beta$ and $\mathrm{TNF} \alpha$ was significantly inhibited at the mRNA and protein level, as determined by RT-PCR (Fig. 2A) and western blot analysis (Fig. 2B), respectively.

Effect of IL-1 $\beta$ and TNF $\alpha$ silencing on GC cell proliferation activity. The results of the CCK8 assay demonstrated that the cell proliferation activity was significantly reduced following co-transfection with siRNA1 and siRNAc (IL-1 $\beta /$ TNF $\alpha$ group, $8.13 \pm 1.01 \%$; control group, $78.18 \pm 3.11 \%$; $\mathrm{P}<0.01$; Fig. $3 \mathrm{~A}$ ).

Effect of IL-1 $\beta$ and TNF $\alpha$ silencing on GC cell colony formation ability. The colony formation assay demonstrated a colony formation rate of $12 \pm 1.12 \%$ in the IL- $1 \beta / \mathrm{TNF} \alpha$ gene silencing 
Table IV. Protein chip screening of various significant inflammatory factors.

\begin{tabular}{|c|c|c|c|}
\hline No. & $\begin{array}{c}\text { Differentially } \\
\text { expressed factors }\end{array}$ & $\begin{array}{c}\text { Fold change } \\
\text { Mean (negative control group)/ } \\
\text { Mean (IL-1 } \beta / \text { TNF } \alpha \text { silencing group) }\end{array}$ & P-value \\
\hline 1 & CCL5 & 2.25 & 0.041 \\
\hline 2 & COX-2 & 3.12 & 0.032 \\
\hline 3 & IL-6 & 4.05 & 0.014 \\
\hline 4 & IL-17A & 2.11 & 0.039 \\
\hline 5 & TGF $\beta$ & 3.12 & 0.035 \\
\hline 6 & MMP9 & 5.09 & 0.001 \\
\hline 7 & SDF-1 $1 \alpha$ & 3.02 & 0.011 \\
\hline
\end{tabular}

IL-1 $\beta$, interleukin-1 $\beta$; TNF $\alpha$, tumor necrosis factor $\alpha$; CCL5, chemokine ligand 5; COX-2, cyclooxygenase-2; TGF $\beta$, transforming growth factor $\beta$; MMP9, matrix metallopeptidase 9; SDF-1 $\alpha$, stromal cell-derived factor $1 \alpha$.

Table V. Associated pathways of various significant inflammatory factors.

\begin{tabular}{llcc} 
Pathway & Database & ID & $\begin{array}{c}\text { Corrected } \\
\text { P-value }\end{array}$ \\
\hline Rheumatoid arthritis & KEGG pathway & mmu05323 & 0.01 \\
Intestinal immune network for IgA production & KEGG pathway & mmu04672 & 0.06 \\
Tumor necrosis factor signaling pathway & KEGG pathway & mmu04668 & 0.06 \\
Inflammatory bowel disease & KEGG pathway & mmu05321 & 0.07 \\
\hline
\end{tabular}

IgA, immunoglobulin A; KEGG, Kyoto Encyclopedia of Genes and Genomes.

group, which was significantly lower than that in the control

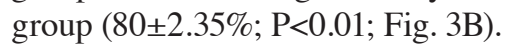

Effect of $I L-1 \beta$ and TNF $\alpha$ silencing on GC cell migration ability. The results of the Transwell assay indicated that the cell migration ability in the IL-1 $\beta / \mathrm{TNF} \alpha$ group $(16 \pm 0.23 \%)$ was lower than that in the control group $(86 \pm 2.7 \%)$ with a significant difference $(\mathrm{P}<0.01)$.

Effect of $I L-1 \beta$ and $T N F \alpha$ silencing on GC cell inflammatory factor expression. The protein microarray analysis of 40 inflammatory factors revealed that there were seven differentially expressed proteins, including chemokine (C-C motif) ligand 5 (CCL5), cyclooxygenase-2 (COX-2), interleukin-6 (IL-6), transforming growth factor $\beta$ (TGF $\beta$ ), interleukin 17A (IL-17A), matrix metallopeptidase 9 (MMP9) and stromal cell-derived factor $1 \alpha(\mathrm{SDF}-1 \alpha)$ when comparing between the IL-1 $\beta /$ TNF $\alpha$ group and the control group (Fig. 4). The fold changes and P-values of these proteins are shown in Table IV.

Pathway analysis of low-expressed inflammatory factors. KEGG pathway enrichment analysis revealed that the differentially expressed protein target genes were enriched in four signaling pathways, namely rheumatoid arthritis, intestinal immune network for IgA production, TNF signaling pathway and inflammatory bowel disease (IBD; Table V). The most correlated pathway was the rheumatoid arthritis pathway; the downloaded visual pathway map from the KEGG database (http://www.kegg.jp/kegg-bin/show_pathway?map05323) is shown in Fig. 5.

\section{Discussion}

Inflammation is strongly associated with tumor development, including GC $(4,6,20)$. Chronic inflammation induces immunosuppression and cancer (21). This study focused on the effect of gene silencing of two inflammatory cytokines, IL-1 $\beta$ and TNF $\alpha$, on GC cell growth. The results suggested that co-suppression of IL-1 $\beta$ and TNF $\alpha$ significantly inhibited the processes of MFC proliferation, colony formation and migration. Furthermore, seven differentially expressed proteins (CCL5, COX-2, IL-6, TGF $\beta$, IL-17A, MMP9 and SDF-1 $\alpha$ ) were identified, and these were observed to be enriched in certain inflammation and immunity-related pathways (rheumatoid arthritis, the intestinal immune network for IgA production, TNF signaling pathway and IBD). These results indicate that co-silencing of the IL-1 $\beta$ and TNF $\alpha$ genes may be an effective option for the suppression of $\mathrm{GC}$ development by regulating the inflammatory, TNF and immune pathways.

TNF $\alpha$ and IL-1 $\beta$ promote tumor cell proliferation and anti-evasion through activation of the nuclear factor- $\kappa \mathrm{B}$ pathway (22). The IL-1 gene cluster, located in 2q13-24, consists of IL-1A, IL-1B and IL-IRN, which encode pro-inflammatory cytokines IL-1 $\alpha$, IL-1 $\beta$ and anti-inflammatory cytokine IL-1r, 

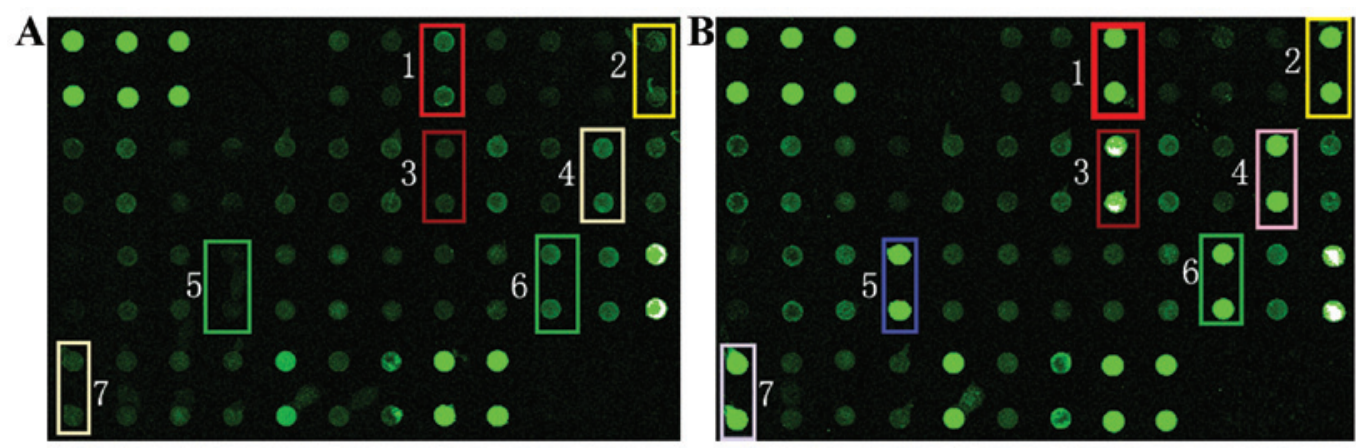

Figure 4. Fluorescence scanning image of the protein microarray in the (A) interleukin-1 $\beta /$ tumor necrosis factor $\alpha$ group and (B) control group. 1, chemokine ligand $5 ; 2$, cyclooxygenase- $2 ; 3$, interleukin- 6 ; 4. interleukin-17A; 5 , transforming growth factor $\beta ; 6$, matrix metallopeptidase $9 ; 7$, stromal cell-derived factor $1 \alpha$.

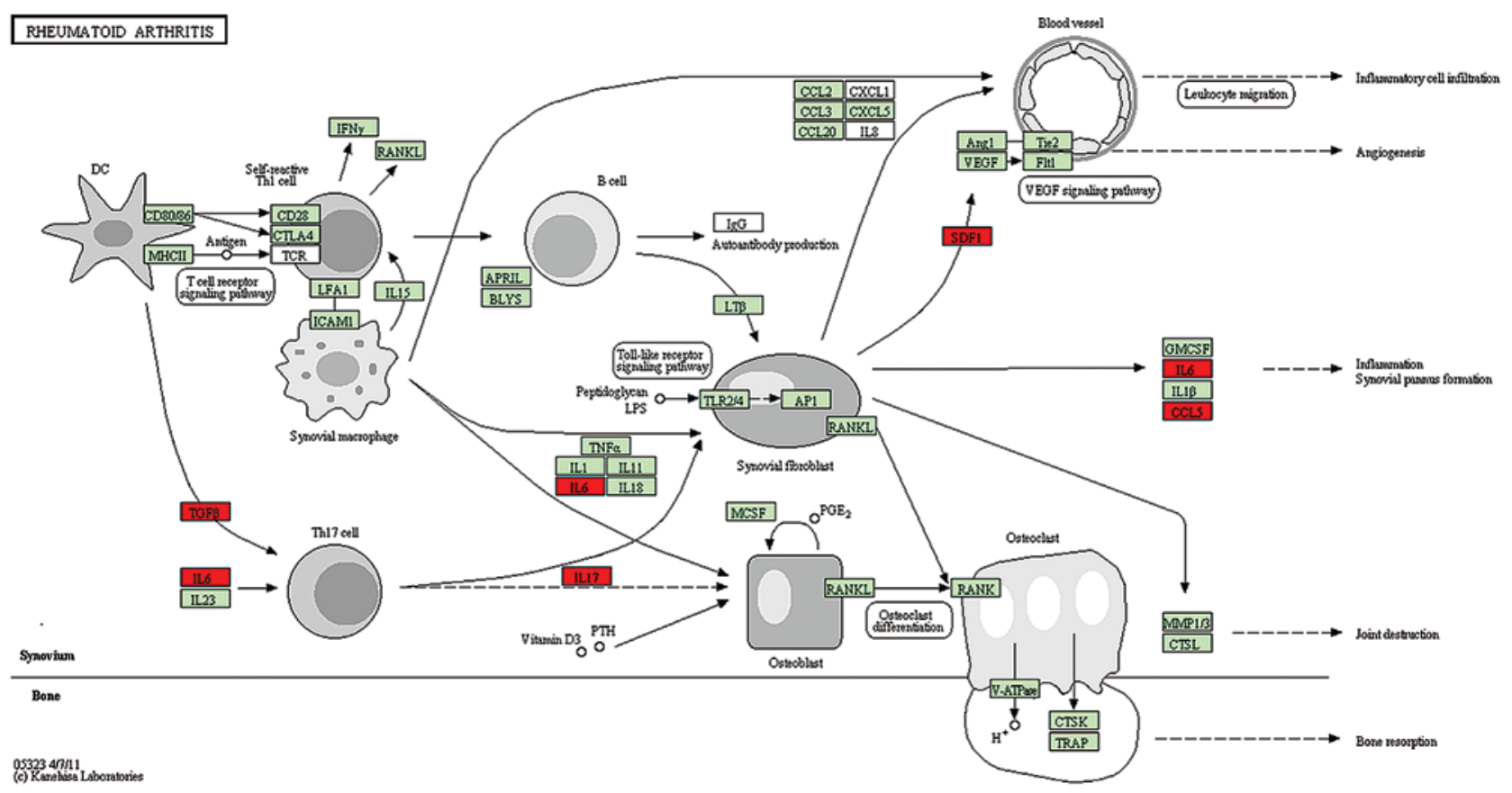

Figure 5. The most correlated signaling pathway was the rheumatoid arthritis pathway (http://www.kegg.jp/kegg-bin/show_pathway?map05323). The red boxes represent the selected differentially expressed proteins.

respectively (23). Due to its genetic polymorphisms being associated with protein expression in regulatory sequences (24), IL-1 has become a candidate gene of GC $(25,26)$. It is reported that individuals carrying the IL- $1 \beta$ and TNF $\alpha$ risk genotype are likely to suffer GC (27). IL-1 $\beta$ promotes gastric atrophy through suppression of Sonic Hedgehog (28). The upregulation of IL-1 $\beta$, IL-8 and COX-2 in patients with chronic gastritis has a significant clinical implication in gastric carcinogenesis (29). Saijo et al reported that secretion of IL-1 $\beta$ into the tumor milieu induces several angiogenic factors including CXCL2 and vascular endothelial growth factor from tumor and stromal cells, thus promoting tumor growth (20). Furthermore, TNF $\alpha$ promotes tumor invasion and metastasis through the upregulation of chemokine CXCR4 and ICAM-1 expression (30). Suppression of TNF $\alpha$ by siRNA nanocomplexes represents an efficient therapy for inflammatory diseases including IBD (31). In this study, co-silencing of IL- $1 \beta$ and TNF $\alpha$ using a siRNA technique in vitro decreased the proliferation rate of cells, indicating that the IL-1 $\beta$ and TNF $\alpha$ genes are positive regulators in
MFC cell proliferation. In addition, the IL-1 $\beta$ and TNF $\alpha$ gene silencing reduced MFC colony growth activity and migration capacity. This may be due to TNF $\alpha$ and IL-1 $\beta$ transferring to the wound by macrophages and neutrophils, and promoting adhesion between GC cells and peritoneal tissue (15).

Following inhibition of IL-1 $\beta$ and TNF $\alpha$, the expression of several inflammatory cytokines, including MMP factors, COX-2, SDF-1 $\alpha$, IL-6, TGF $\beta$ and IL-17A, were significantly reduced. TNF $\alpha$ and IL-1 $\beta$ are the upstream genes of MMP, COX-2, IL-6 and IL-17A. Accumulation of MMP and COX-2 induces secretion of SDF-1 $\alpha$, which further promotes inflammation and angiogenesis (32). TGF $\beta$ promoted GC cell proliferation, invasion and metastasis $(33,34)$. CCL5 plays a key role in cancer cell invasion and tumorigenic effect (35). In addition, the pathway enrichment analysis indicated that these genes were enriched in the inflammatory, TNF and immune pathways. These results have prompted the hypothesis that the mechanism of IL-1 $\beta$ and TNF $\alpha$ gene silencing in GC cell proliferation and migration may involve the inflammatory 
and immune pathways. Other studies have indicated that TNF $\alpha / T N F R 1$ signaling promotes gastric tumorigenesis through the induction of NADPH oxidase organizer 1 and guanine nucleotide-binding protein subunit $\alpha 14$ in tumor cells (36). In addition, other genetic factors have also been demonstrated to affect the susceptibility of GC, including the prostate stem cell antigen gene and Mucin 1 gene in the Japanese population (37) and zinc finger and BTB domain containing 20, protein kinase AMP-activated $\alpha 1$ catalytic subunit and phospholipase $\mathrm{C} \varepsilon 1$ in the Chinese population $(38,39)$. Further research is warranted to understand the mechanisms and explore effective treatments for GC.

This study demonstrates that IL- $1 \beta$ and TNF $\alpha$ play a critical role in the process of MFC cell proliferation, migration and invasion, and that silencing of IL-1 $\beta$ and TNF $\alpha$ genes could inhibit these processes. These results suggest that IL-1 $\beta$ and $\mathrm{TNF} \alpha$ gene silencing may be an effective approach for the treatment of GC.

\section{References}

1. Bray F, Ren JS, Masuyer E and Ferlay J: Global estimates of cancer prevalence for 27 sites in the adult population in 2008. Int J Cancer 132: 1133-1145, 2013.

2. Arnold M, Moore SP, Hassler S, et al: The burden of stomach cancer in indigenous populations: a systematic review and global assessment. Gut 63: 64-71, 2014.

3. Siegel R, Ma J, Zou Z and Jemal A: Cancer statistics, 2014. CA Cancer J Clin 64: 9-29, 2014.

4. Qadri Q, Rasool R, Gulzar GM, Naqash S and Shah ZA: H.pylori infection, inflammation and gastric cancer. J Gastrointest Cancer 45: 126-132, 2014.

5. Machado JC, Figueiredo C, Canedo P, et al: A proinflammatory genetic profile increases the risk for chronic atrophic gastritis and gastric carcinoma. Gastroenterology 125: 364-371, 2003.

6. Fox JG and Wang TC: Inflammation, atrophy and gastric cancer. J Clin Investig 117: 60-69, 2007.

7. Uemura N, Okamoto S, Yamamoto S, et al: Helicobacter pylori infection and the development of gastric cancer. N Engl J Med 345: 784-789, 2001.

8. Coussens LM and Werb Z: Inflammation and cancer. Nature 420: $860-867,2002$

9. Hatakeyama M and Higashi H: Helicobacter pylori CagA: a new paradigm for bacterial carcinogenesis. Cancer Sci 96: 835-843, 2005

10. Hyland PL, Lin SW, Hu N, et al: Genetic variants in fas signaling pathway genes and risk of gastric cancer. Int J Cancer 134: 822-831, 2014.

11. Yu G, Tang B, Yu PW, Peng ZH, Qian F and Sun G: Systemic and peritoneal inflammatory response after laparoscopic-assisted gastrectomy and the effect of inflammatory cytokines on adhesion of gastric cancer cells to peritoneal mesothelial cells. Surg Endosc 24: 2860-2870, 2010.

12. Bo T, Zhihong P, Peiwu Y, et al: General complications following laparoscopic-assisted gastrectomy and analysis of techniques to manage them. Surg Endosc 23: 1860-1865, 2009.

13. Chang WJ, Du Y, Zhao X, Ma LY and Cao GW: Inflammation-related factors predicting prognosis of gastric cancer. World J Gastroenterol 20: 4586-4596, 2014.

14. Amedei A, Benagiano M, della Bella C, Niccolai E and D'Elios MM: Novel immunotherapeutic strategies of gastric cancer treatment. J Biomed Biotechnol 2011: 437348, 2011.

15. Rusai K, Huang H, Sayed N, et al: Administration of interleukin-1 receptor antagonist ameliorates renal ischemia-reperfusion injury. Transpl Int 21: 572-580, 2008

16. Basso D, Scrigner M, Toma A, et al: Helicobacter pylori infection enhances mucosal interleukin-1 beta, interleukin-6, and the soluble receptor of interleukin-2. Int J Clin Lab Res 26: 207-210, 1996.
17. Friedmann E, Hauben E, Maylandt K, et al: SPPL2a and SPPL2b promote intramembrane proteolysis of TNFalpha in activated dendritic cells to trigger IL-12 production. Nat Cell Biol 8: 843-848, 2006.

18. Chang WW, Zhang L, Su H and Yao YS: An updated meta-analysis of transforming growth factor- $\beta 1$ gene: three polymorphisms with gastric cancer. Tumour Biol 35: 2837-2844, 2014.

19. Xie C, Mao X, Huang J, et al: KOBAS 2.0: a web server for annotation and identification of enriched pathways and diseases. Nucleic Acids Res 39: W316-W322, 2011.

20. Saijo Y, Tanaka M, Miki M, et al: Proinflammatory cytokine IL-1beta promotes tumor growth of lewis lung carcinoma by induction of angiogenic factors: in vivo analysis of tumor-stromal interaction. J Immunol 169: 469-475, 2002.

21. Kanterman J, Sade-Feldman M and Baniyash M: New insights into chronic inflammation-induced immunosuppression. Semin Cancer Biol 22: 307-318, 2012.

22. Lin Y, Bai L, Chen W and Xu S: The NF-kappaB activation pathways, emerging molecular targets for cancer prevention and therapy. Exp Opin Ther Targets 14: 45-55, 2010.

23. Dinarello C, Arend W, Sims J, Smith D, et al: IL-1 family nomenclature. Nat Immunol 11: 973, 2010.

24. Hwang IR, Kodama T, Kikuchi S, Sakai K, Peterson LE, Graham DY and Yamaoka Y: Effect of interleukin 1 polymorphisms on gastric mucosal interleukin 1beta production in helicobacter pylori infection. Gastroenterology 123: 1793-1803, 2002.

25. Xing PX, Kan SF, Wand HC, Gao W, Zeng QD and Wang YS: Serum level and genotype of interleukin-1 $\beta$ or interleukin-1 receptor antagonist in patients with gastric cancer. Chin J Microbiol Immunol 28: 435-439, 2008.

26. Kai H, Kitadai Y, Kodama M, et al: Involvement of proinflammatory cytokines IL-1beta and IL-6 in progression of human gastric carcinoma. Anticancer Res 25: 709-713, 2005.

27. El-Omar EM, Carrington M, Chow WH, et al: Interleukin-1 polymorphisms associated with increased risk of gastric cancer. Nature 404: 398-402, 2000.

28. Waghray M, Zavros Y, Saqui-Salces M, et al: Interleukin-1beta promotes gastric atrophy through suppression of sonic hedgehog. Gastroenterology 138: 562-572, 2010.

29. Bartchewsky W Jr, Martini MR, Masiero M, Squassoni AC, Alvarez MC, Ladeira MS, Salvatore D, Trevisan M, Pedrazzoli J Jr and Ribeiro ML: Effect of Helicobacter pylori infection on IL-8, IL-1beta and COX-2 expression in patients with chronic gastritis and gastric cancer. Scandinavian J Gastroenterol 44: 153-161, 2009.

30. Hayden MS and Ghosh S: Signaling to NF-kappaB. Genes Dev 18: 2195-2224, 2004

31. Laroui H, Theiss AL, Yan Y, Dalmasso G, Nguyen HT, Sitaraman SV and Merlin D: Functional TNFa gene silencing mediated by polyethyleneimine/TNF $\alpha$ siRNA nanocomplexes in inflamed colon. Biomaterials 32: 1218-1228, 2011.

32. Lakemeier S, Braun J, Efe T, Foelsch C, Archontidou-Aprin E, Fuchs-Winkelmann S, Paletta JR and Schofer MD: Expression of matrix metalloproteinases 1,3 and 9 in differing extents of tendon retraction in the torn rotator cuff. Knee Surg Sports Traumatol Arthrosc 19: 1760-1765, 2011

33. Oft M, Heider KH and Beug $\mathrm{H}$ : TGFbeta signaling is necessary for carcinoma cell invasiveness and metastasis. Curr Biol 8: 1243-1252, 1998.

34. Joan Massagué: TGF $\beta$ in cancer. Cell 134: 215-230, 2008.

35. Yaal-Hahoshen N, Shina S, Leider-Trejo L, et al: The chemokine CCL5 as a potential prognostic factor predicting disease progression in stage II breast cancer patients. Clin Cancer Res 12: 4474-4480, 2006.

36. Oshima $\mathrm{H}$, Ishikawa $\mathrm{T}$, Yoshida GJ, et al: TNF- $\alpha / \mathrm{TNFR} 1$ signaling promotes gastric tumorigenesis through induction of Noxol and Gna14 in tumor cells. Oncogene 33: 3820-3829, 2014.

37. Saeki N, Ono H, Sakamoto H and Yoshida T: Genetic factors related to gastric cancer susceptibility identified using a genome-wide association study. Cancer Sci 104: 1-8, 2013.

38. Shi Y, Hu Z, Wu C, et al: A genome-wide association study identifies new susceptibility loci for non-cardia gastric cancer at 3q13.31 and 5p13.1. Nat Genet 43: 1215-1218, 2011.

39. Abnet CC, Freedman ND, Hu N, et al: A shared susceptibility locus in PLCE1 at 10q23 for gastric adenocarcinoma and esophageal squamous cell carcinoma. Nat Genet 42: 764-767, 2010. 